Universidade de Brasília

Centro de Excelência em Turismo

Contribuições da Psicologia do Desenvolvimento para Formação de Guias em Ecoturismo

Luciana de Amorim Halushuk

Mírian Barbosa Tavares Raposo

Monografia apresentada ao Centro de Excelência em Turismo da Universidade de Brasília como requisito parcial para obtenção do certificado de Especialista em Ecoturismo. 



\author{
Universidade de Brasília \\ Centro de Excelência em Turismo \\ Curso de Especialização em Ecoturismo
}

\title{
Contribuições da Psicologia do Desenvolvimento para a Formação de Guias em Ecoturismo
}

\author{
Luciana de Amorim Halushuk
}

Banca examinadora
Mírian Barbosa Tavares Raposo, Mestre em Psicologia
Orientadora

Membro da Banca

Brasília, DF, 25 de março de 2003 
Halushuk, de Amorim Luciana

Contribuições da Psicologia do Desenvolvimento para a Formação de Guias em Ecoturismo / Luciana de Amorim Halushuk.

$55 \mathrm{f}$.

Monografia (especialização) - Universidade de Brasília.

Centro de Execelência em Turismo. Brasília, 2003.

Área de concentração: Ecoturismo

Orientadora: Mírian Barbosa Tavares Raposo.

1. Ecoturismo 2. Educação 3. Psicologia do Desenvolvimento 
Luciana de Amorim Halushuk

Contribuições da Psicologia do Desenvolvimento para Formação de Guias em Ecoturismo

Comissão avaliadora

Professor(a) orientador(a)

Brasília, DF, 25 de março de 2003 


\section{AGRADECIMENTO}

Agradeço à minha orientadora Mírian Raposo que, com muita paciência e dedicação, auxiliou-me na construção desta monografia. 
"Apenas o sábio mantém o todo constantemente na mente, jamais esquece o mundo, pensa e age em relação ao cosmo."

Groethuysen 


\section{RESUMO}

Este estudo apresenta contribuições da psicologia do desenvolvimento no processo de formação de guias em ecoturismo. Para chegar-se a esse ponto, num primeiro momento buscou-se esclarecer 0 significado do conceito de ecoturismo. Termo por si só bastante complexo. Logo em seguida, aborda-se questões referentes à educação ambiental, cujas concepções variam muito por resultar de posturas filosóficas diferenciadas. Posteriormente relacionou-se a educação ambiental com o ecoturismo e, fundamentalmente, destacou-se o papel do guia no empreendimento ecoturístico e das diferentes representações sociais dos conceitos de meio ambiente e cultura. Em seguida, descreveram-se sínteses das teorias de vários estudiosos da psicologia, apontando sugestões que poderão propiciar ao guia uma formação capaz de suprir as exigências inerentes às atividade ecoturísticas, pautadas por princípios que aliam sustentabilidade ecológica, econômica e sociocultural. 


\begin{abstract}
This study presents contributions of the psychology of development to ecoturism guides formation process. To reach this point, it was firstly tried to clarify the meaning of ecoturism concept, a very complex term by itself. Then questions concerning environmental education were raised, whose conceptions greatly differ for resulting from philosophical postures. Next, environmental education was related to ecoturism and, fundamentally, the role of the guide in the ecoturistic enterprise was highughted, attempting to the importance of noticing the differences of social representations of the concepts of environment and culture. At last, syntheses of various theorists of human development were described, pointing at suggestions that will be able to provide the guide whit a formation able to supply the inherent requirements to the ecoturistic activities, which must be ruled by principles that ally ecologic, economic and socio cultural self- sufficiency.
\end{abstract}




\section{SUMÁRIO}

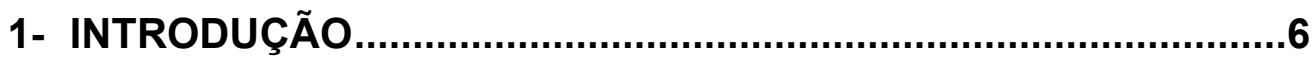

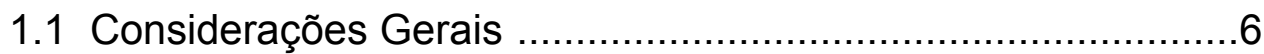

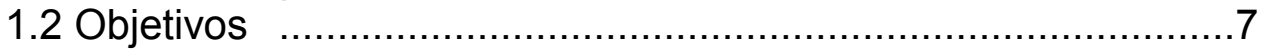

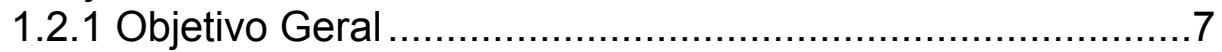

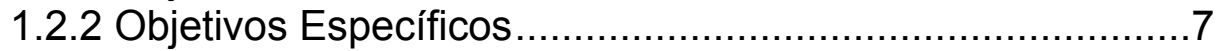

1.3 Importância ................................................................

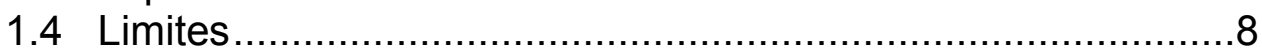

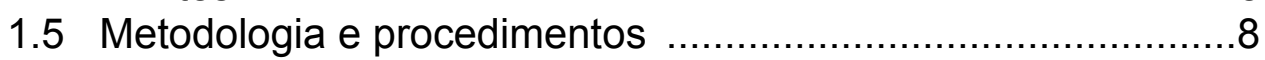

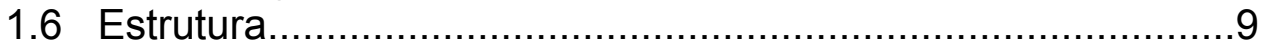

2- ENTENDENDO O ECOTURISMO ................................................10

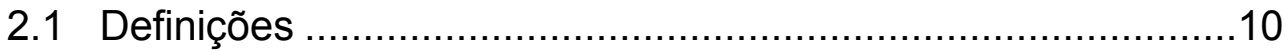

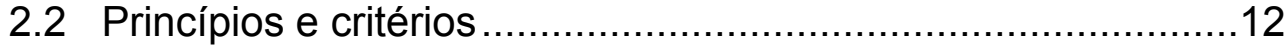

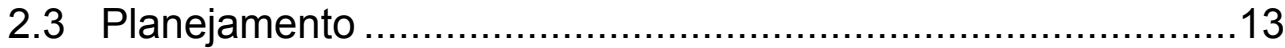

2.4 Em busca da sustentabilidade ........................................14

3- EDUCAÇÃO AMBIENTAL: CAMINHOS POSSÍVEIS......................18

3.1 Educação ambiental e suas diferentes abordagens .................18

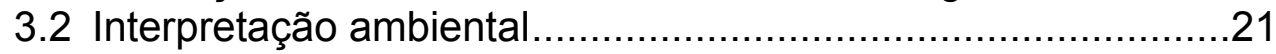

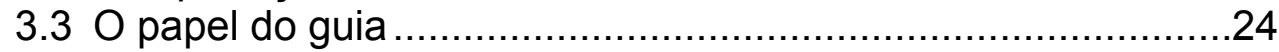

4- FORMAÇÃO DE GUIAS E AS VÁRIAS CONCEPÇÕES DE

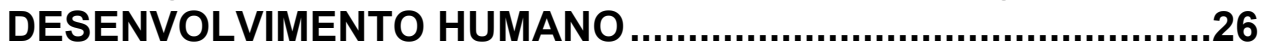

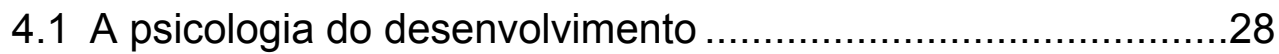

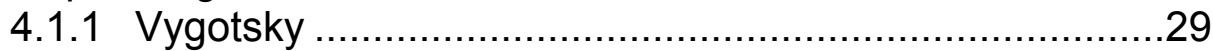

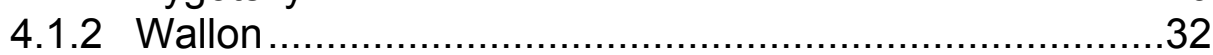

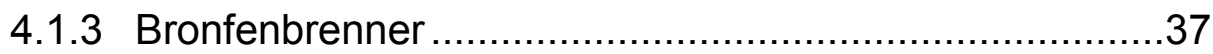

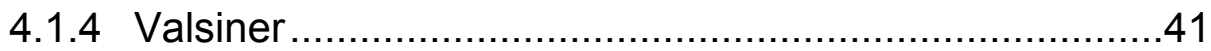

4.1.5 Baltes ................................................................ 44

4.2 Pressupostos teóricos para a formação de guias ……….......47

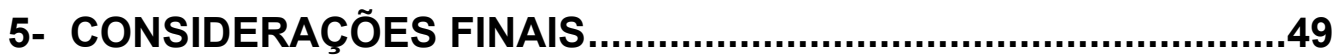

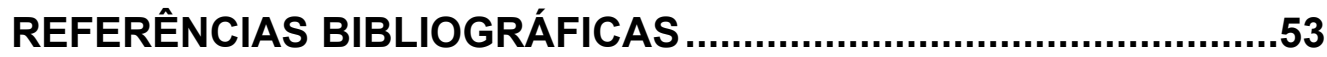




\section{INTRODUÇÃO}

\section{1- Considerações gerais}

Nesta monografia, abordar-se-ão alguns aspectos considerados relevantes para a formação de guias ou condutores de visitantes ecoturísticos. pois estes, muitas vezes, entram nesse mercado de trabalho sem a menor condição para exercer o papel de fomentador de educação ambiental, em virtude de sua formação deficiente. Percebe-se que geralmente esse profissional advém da classe popular, com baixo nível de escolaridade e encontra na guiagem de ecoturistas uma possibilidade de melhoria no padrão de vida.

Embora a EMBRATUR (Instituto Brasileiro de Turismo), considere guias apenas pessoas formadas em cursos credenciados pela mesma, um grande número de associações de condutores de visitantes recebem pouco ou nenhum apoio do governo, embora continuem a formar esses profissionais. Apenas o nome guia ou condutor de visitantes não diferencia a atividade exercida por ambos. Isso gera o mesmo nível de expectativa no visitante que pretende conhecer um lugar, interagir com ele e ampliar seus conhecimentos a respeito dele.

Como cresceram as atividades ligadas ao ecoturismo, passou-se a se exigir mais profissionalismo do guia, mas ainda não se valoriza a profissão como se deveria. Nesse sentido, estudos que possam contribuir para uma conseqüente melhoria na formação desse importante profissional no processo de educação do visitante poderão ampliar mecanismos que integrem o homem e o ambiente natural. Para que isso ocorresse, buscaram-se contribuições da psicologia do desenvolvimento humano, que em diversas abordagens, interessou-se pela modo como se constrói o conhecimento, fator esse que poderá influenciar a maneira de pensar e de agir do guia. 


\section{2 - Objetivos}

\subsection{1 - Objetivo geral:}

Apresentar contribuições da psicologia do desenvolvimento na formação de guias ou condutores de visitantes ecoturísticos.

\subsection{2 - Objetivos específicos:}

Ampliar as discussões sobre a melhoria na qualidade de formação de recursos humanos na atividade ecoturística;

Mostrar a importância do guia no processo de educação do visitante e no contexto da atividade turística;

Reconhecer na psicologia contribuições para formação de guias, visando à atividade ecoturística.

Relacionar bibliografia específica para interessados no assunto abordado.

\section{3- Importância}

Não se pode questionar a importância de estudos realizados na área de formação de recursos humanos, objetivando a atuação em atividades como o ecoturismo. Neste trabalho, tratar-se-á especialmente da formação de guias, tendo em vista seu contato direto com os visitantes.

"A dependência que o ecoturismo tem da natureza, em oposição a outras formas de turismo, nas quais a natureza é incidental à experiência, inclui a motivação turística de satisfazer uma necessidade educacional, que deriva das interações com o ambiente natural." (Wearing e Neil, 2001,p.12)

O ecoturismo pressupõe a existência de educação ambiental e o guia age como fomentador de educação ambiental, podendo assumir o papel de mediador na construção desse conhecimento ou apenas caracterizar-se como um mero reprodutor de informações. Para que esse profissional possa 
assumir uma postura sintonizada com os pressupostos da educação ambiental, deve desenvolver uma visão holística e contextual, admitindo a ampla dimensão do conceito de meio ambiente e para isso necessita-se pensar em uma formação capaz de proporcionar-lhe condições para desenvolver tais habilidades.

Nesse sentido necessita-se formar guias para atuarem enquanto educadores ambientais, uma vez que a educação pode, potencialmente, transformar uma realidade.

Este estudo visa colaborar para que os atores sociais envolvidos nas atividades ecoturísticas possam aperfeiçoar seus cursos de formação de guias, contribuindo para o sucesso de práticas educativas que proporcionem uma melhor interação entre o homem e o ambiente natural.

\section{4- Limites}

Apesar de elaborado sob critérios rigorosos, o presente trabalho apresenta limitação teórica específica em relação à formação de guias, uma vez que se discutiu pouco essa temática no meio acadêmico e até o momento não se pode contar com uma bibliografia específica sobre o problema.

\section{5- Metodologia utilizada}

A realização desta monografia implicou a utilização de pesquisa exploratória, porque o trabalho objetiva aprimorar idéias, haja vista terem-se realizado poucos estudos nessa área.

“ A pesquisa exploratória procura aprimorar idéias ou descobrir intuições. Caracteriza -se por possuir um planejamento flexível envolvendo em geral levantamento bibliográfico, entrevistas com pessoas experientes e análises de exemplos similares. As formas mais comuns de apresentação das pesquisas exploratórias são a pesquisa bibliográfica e o estudo de caso". (Dencker, 2002, p.124.).

A fim de coletarem-se dados necessários para se atingirem os objetivos propostos deste trabalho, realizou-se a pesquisa bibliográfica, o que 
se justifica tanto pela amplitude que a mesma proporciona, como pela economia de tempo, a possibilidade de discussão conceitual e revisão bibliográfica.

\section{6- Estrutura}

O primeiro capítulo apresenta uma introdução onde se descrevem os objetivos geral e específico, a importância do tema, a metodologia utilizada, a limitação e a estrutura deste trabalho.

O segundo procura trazer informações básicas a respeito do ecoturismo ou temas que estão diretamente ligados ao seu desenvolvimento como seus conceitos, critérios, planejamento e sustentabilidade.

O terceiro trata especificamente de educação ambiental como uma atividade inerente ao ecoturismo, suas diferentes abordagens, interpretação ambiental e o papel do guia.

O quarto sintetiza trabalhos de diversos teóricos que tratam do desenvolvimento humano.

O último capítulo, tece considerações finais, relacionando todos os temas desenvolvidos e apresentando ainda contribuições da psicologia do desenvolvimento no processo de formação de guias em ecoturismo. 


\section{2- ENTENDENDO O ECOTURISMO}

\section{1- Definições:}

O ecoturismo, consiste num termo empregado mais amplamente a partir da década de oitenta no mercado brasileiro. As mais variadas belezas naturais e reservas do país ajudaram a difundir ainda mais a utilização da palavra.

"Termos como turismo natural, turismo científico, turismo cultural, turismo responsável, turismo ambiental, ecoturismo, turismo de aventura e muitos outros, são largamente utilizados pelo mercado turístico e, nem sempre, suas atividades são desenvolvidas baseadas em atividades de turismo ambientalmente e socialmente responsáveis. (Salvati, 2002 ,apud, Kutay, 1993).

Encontram-se pessoas que vêem o ecoturismo como uma prática de reencontro com a natureza, baseada no respeito e na responsabilidade para com o ambiente $\mathrm{e}$ as comunidades locais, mas isso não ocorre constantemente.

"Em meados dos anos 80, começaram a surgir as primeiras agências de ecoturismo, especialmente na cidade de São Paulo, cujos empreendedores acreditavam que o turismo desenvolvido em ambientes naturais era uma forma alternativa de crescimento pessoal, interior e de formação de uma consciência ambiental e ecológica". (Barros, 1999, apud Ibid, 1998).

O termo ecoturismo apresenta um sentido muito amplo, pois envolve sustentabilidade, lazer, educação, conceitos já complexos por sós. Nesta monografia tomar-se-á como ponto de partida o conceito colocado pela EMBRATUR:

“... um segmento da atividade turística que utiliza , de forma sustentável, o patrimônio natural e cultural, incentiva sua conservação e busca a formação de uma consciência 
ambientalista através da interpretação do ambiente, promovendo o bem estar das populações envolvidas." ${ }^{1}$

De acordo com o TRADE (Grupo de empreendedores de turismo), o mesmo termo designa:

"Atividade turística realizada em área natural com o objetivo de observação e conhecimento de flora, da fauna e dos aspectos cênicos (com ou sem o sentido de aventura); prática de esportes e realização de pesquisas científicas".

( Ruschel e Associados 1995, p.7).

Ocorre aí um exemplo de como o conceito de ecoturismo pode variar de acordo com interesses e ideologias. O primeiro considera práticas sustentáveis, conservação e respeito a comunidades locais. O segundo aponta a falta de comprometimento com a sustentabilidade e a conservação, despreocupações ainda comuns nas práticas turísticas atualmente.

Explorar-se-á o conceito colocado pela EMBRATUR, porque este abrange não só questões importantes para a melhoria da qualidade de vida das populações das áreas visitadas, como também inclui a conservação dos patrimônios cultural e natural, evidenciando a importância da formação de uma consciência ambientalista que, necessariamente, advém da educação ambiental.

\footnotetext{
${ }^{1}$ EMBRATUR- Diretrizes para Uma Política Nacional de Ecoturismo, 1994, p.19.
} 


\section{2- Princípios e critérios:}

Objetivando diferenciar o ecoturismo do turismo convencional, devese ressaltar princípios e critérios colocados pelo projeto OCE - Oficinas de Capacitação em Ecoturismo, 1994, que contou com a participação de várias instituições, inclusive o MMA (Ministério do Meio Ambiente), EMBRATUR (Instituto Brasileiro de Turismo) e SENAC (Serviço Nacional de Aprendizagem Comercial).

.Princípios:

- Conservação e uso sustentável dos recursos naturais e culturais;

- Informação e interpretação ambiental;

- Geração de recursos, já que se trata de um empreendimento;

- Reversão dos benefícios para a comunidade local e para a conservação dos recursos naturais e culturais;

- Envolvimento da comunidade local.

Critérios:

- Manejo e administração verde do empreendimento;

- Associação e parceria entre os setores governamentais e nãogovernamentais locais, regionais e nacionais;

- Educação ambiental para o turista e para a comunidade local;

- Formação de guias conscientes, interessados e responsáveis;

- Planejamento integrado com preferência à regionalização;

- Promoção de experiências únicas e inesquecíveis em um destino exótico;

- Monitoramento e avaliação constante;

- Código de ética para o mercado do ecoturismo.

Esses príncipios e critérios constituem-se a base para existência do ecoturismo e a fim de colocá-los em prática, não se pode prescindir de guias 
responsáveis e interessados, o que evidentemente pressupõe uma formação adequada dos profissionais da área.

\section{3 - Planejamento:}

O planejamento em ecoturismo revela-se ferramenta importante para que ele represente atividade sustentável. Acredita-se que ao orientá-lo por princípios e critérios, como os citados anteriormente, pode-se chegar ao objetivo previsto, evitando-se as situações inesperadas ou adaptando-se a elas. O ecoturismo, visando apenas ao mercado e sem se utilizar de um planejamento prévio, pode causar mais danos que o turismo convencional, haja vista que o primeiro ocorre em áreas extremamente frágeis.

"O objetivo do planejamento do ecoturismo é, em geral, identificar as principais questões que podem afetar seu desenvolvimento e gerenciamento, além de desenvolver políticas e programas para ajudar a tornar a indústria mais viável e sustentável. O conteúdo de um plano de ecoturismo deverá incluir, em primeiro lugar, a percepção e os objetivos da existência dessa estratégia e uma base racional para sua existência. A estratégia também exige a identificação e a consulta dos diversos grupos de interessados e representantes do setor de ecoturismo, antes da busca de uma definição de ecoturismo ou do desenvolvimento de um turismo sustentável. A descrição dos impactos do ecoturismo sobre as dimensões ambientais, econômicas, sociais e culturais deverá suscitar questões que devem ser abrangidas por meio de objetivos e ações." (Wearing e Neil, 2001, p.42)

Ao planejar-se o ecoturismo, os mais variados setores da sociedade, principalmente as populações locais, devem participar do processo pois essa atividade certamente afetará suas vidas. Os setores mais diretamente ligados às atividades ecoturísticas e que devem participar de todo o processo de planejamento, execução e monitoramento abrangem:

"Poder público: responsável por dotar as localidades de infra- estrutura mínima para receber o turista.

População local: que mostrará seu modo de vida, costumes, festas, por meio de produtos, serviços, e educação 
ambiental; e estará organizada para fazer com que os recursos e benefícios sociais gerados pelo ecoturismo sejam bem distribuídos.

Fornecedores : empresas e/ ou pessoas que colocarão à disposição dos visitantes serviços de hospedagem, alimentação, transportes, entretenimento, guias, comércio, entre outros.

Operadoras de turismo: empresas que criam o pacote turístico, encarregando-se de promover e vender atrações locais por meio do agente de viagens ou diretamente ao consumidor nacional ou internacional.

Agentes de viagens: empresas que recebem dos operadores de turismo o pacote ecoturístico pronto para ser vendido, encarregando-se de vendê-lo ao consumidor. " 2

Ao planejar-se a atividade ecoturística, as pessoas envolvidas devem não só respeitar as características obviamente diversificadas das diferentes áreas, mas também preocupar-se com a geração de empregos, o que dependerá da capacitação profissional da comunidade. Por isso deve-se pensar o empreendimento de modo a absorverem-se as pessoas da própria comunidade no mercado, garantindo-lhes renda e portanto, a conseqüente sustentabilidade econômica da região.

\section{4 - Em busca de sustentabilidade}

O ecoturismo, como toda atividade humana, envolve aspectos positivos e negativos tanto para o ambiente natural, como para os setores econômico e sociocultural. Isso vai depender do planejamento e monitoramento da atividade visando à sua sustentabilidade. O Manual do Ecoturismo do MMA/Proecotur (Turismo verde - Programa de Desenvolvimento do Ecoturismo na Amazônia Legal) relaciona os aspectos ambientais, econômicos e

\footnotetext{
${ }^{2}$ Ecoturismo: visitar para conservar e desenvolver a Amazônia / Manual de ecoturismo elaborado por : Luiz Fernando Ferreira; Maria do Carmo Barêa Coutinho. Brasília: MMA/SCA/Proecotur, 2002 , p.27.
} 
socioculturais que podem influenciar a existência de um ecoturismo sustentável, apontando-lhes os lados positivo e negativo.

No que concerne ao meio ambiente, apresentam-se como positivas as seguintes ações:

- Destinação de recursos financeiros para conservação e incentivo à pesquisa científica;

- Promoção da educação ambiental e maior consciência ambiental nas populações;

- Viabilização de tecnologias ambientalmente sustentáveis;

- Estímulo à implantação de infra-estrutura básica, como saúde, segurança, educação, comunicação e comércio.;

- Valorização de áreas naturais, cujo desenvolvimento deve associar-se à sua conservação.

Por outro lado, na mesma realidade, ocorrem ações prejudiciais tais como:

- Alterações nos comportamentos, nos hábitos alimentares e na reprodução dos animais silvestres pelo excesso de visitação e/ou presença de lixo;

- Mudanças no quantitativo das populações silvestres;

- Comércio ilegal de espécies silvestres e de artesanatos que utilizam órgãos, penas ou couro de animais;

- Poluição tanto do ar, água, solo, como a sonora e visual;

- Abertura de estradas, trilhas e atalhos inadequados;

- Compactação e erosão do solo.

Quanto ao aspecto econômico, constata-se que este também reflete ações positivas tais como:

- Geração de renda e emprego;

- Utilização da infra-estrutura já existente;

- Desenvolvimento com produtos locais;

- Complementação em outras atividades econômicas. 
Entretanto nele mesmo pode-se enumerar problemas tais como:

- Inflação;

- Diminuição de emprego na baixa temporada;

- Prejuízos econômicos como conseqüência de boatos, problemas com doenças, mudanças no setor financeiro;

- Economia dependente o ecoturismo como única fonte de renda.

Em relação ao aspecto sociocultural do empreendimento, existe o lado positivo advindo das seguintes ações:

- Contribuição para a educação;

- Estímulo ao entendimento e a paz;

- Redução de barreiras entre as pessoas, tanto as advindas de raça, cor, sexo e cultura, como as decorrentes de preferências políticas ou religiosas;

- Reforço na conservação de heranças e tradições com valorização da cultura local.

Entretanto, mais uma vez ocorrem ações negativas tais quais:

- Antipatia pelo excesso de visitantes;

- Descaracterização da cultura local;

- Desentendimentos entre a comunidade local e novos moradores;

- Aumento da criminalidade.

Alcançar-se a sustentabilidade do ecoturismo constitui-se tarefa difícil, mas não impossível. Necessita-se que tanto turistas quanto comunidades locais exijam mudanças que garantam viabilidade ecológica, econômica e sociocultural dessa atividade. Para que turistas e comunidades envolvidas cheguem a esse nível de entendimento, todos os setores da sociedade devem contribuir para ampliar essa discussão.

Nesse emaranhado de conceitos difusos e complexos que envolvem o termo ecoturismo, pretende-se apontar neste trabalho contribuições da psicologia do desenvolvimento, objetivando-se a formação de guias. A fim de 
subsidiarem-se essas discussões, é importante que, além de esclarecerem-se os aspectos gerais que envolvem essa atividade, reflita-se também sobre práticas de educação ambiental, pois as mesmas envolvem diretamente o guia e sua formação. 


\section{3- EDUCAÇÃO AMBIENTAL: CAMINHOS POSSÍVEIS}

\section{1- Educação ambiental e suas diferentes abordagens:}

O sucesso de um empreendimento ecoturístico, dependerá de vários aspectos. Um deles aparece com mais freqüência nas citações dos estudiosos do turismo: a educação ambiental. Mesmo não se reconhecendo na educação ambiental uma panacéia para todos os problemas que envolvem um empreendimento ecoturístico, necessita-se ampliar as discussões, pensandose não só nas relações existentes entre o homem e a natureza, mas também nas diferentes concepções de meio ambiente e cultura.

"Nessa abordagem, as relações sociais envolvem não só interações entre indivíduos, grupos ou classes, mas compreendem as relações desses com a natureza. Logo, pensar a natureza implica refletir acerca da transformação do indivíduo, sendo esta mudança constituída em cada fase da existência social. O modo como nos inserimos em um ambiente é essencialmente um conjunto de relações sociais, portanto uma alteração radical nestas relações depende de uma mudança estrutural da sociedade em questão". (Loureiro, 2000, apud Redclift, 1997, p 16).

Segundo, Reigota (2001), tem-se promovido a educação ambiental a partir da concepção de meio ambiente, visto de maneira diferente por ecólogos, psicólogos e geógrafos. Como não há um consenso entre vários conceitos, pode-se dizer que a noção de meio ambiente consiste numa representação social, nas representações sociais encontramos os conceitos científicos da maneira como foram internalizados pelas pessoas. $O$ termo meio ambiente na maioria das vezes define-se de acordo com o senso comum, incluindo preconceitos, ideologias e características específicas das atividades cotidianas (sociais e profissionais) das pessoas.

A educação ambiental acaba envolvendo diversas posturas ambientalistas, em virtude de sua característica altamente política. No processo incluem-se movimentos sociais de filiações ideológicas diferenciadas, políticas públicas e partidos políticos. A este fato aliam-se estilos de vida alternativos, 
opções e hábitos de consumo, o que acrescenta a essa atividade muito mais que uma simples visão pedagógica.

Loureiro (2000, citando Moraes 1997), apresenta três posturas ambientalistas vigentes: o naturalismo, onde se abordam os problemas de maneira a-histórica, ignorando-se as relações sociais, processo que condiciona o indivíduo às relações naturais e à sua dinâmica. A ação humana, assim vista, revela-se antrópica (centrada exclusivamente no homem) e podese interpretá-la apenas a partir das ciências biológicas. Evidencia-se também a postura tecnicista em que se apontam as soluções técnicas de manejo e de gestão de recursos naturais como capazes de resolver todos os problemas ambientais decorrentes da exploração de uma área. Por último, destaca-se a visão baseada no contexto do romantismo ingênuo, própria dos que pretendem mostrar-se politica e ecologicamente corretos em relação à natureza, embora desconsiderem-na ao não perceber a inevitável ação humana sobre ela.

O manual de educação ambiental do curso básico a distância do Ministério do Meio Ambiente ${ }^{3}$,coloca duas diferentes abordagens de educação ambiental formal: a vertente ecológica preservacionista e a vertente socioambiental.

A primeira concebe a natureza como algo onde não se inclui o ser humano. Os preservacionistas atribuem valores éticos e estéticos a uma natureza virgem e não consideram os aspectos políticos e econômicos derivados do estilo dominante como causadores da degradação ambiental. Essa vertente postula uma volta às comunidades naturais e primitivas, idealizando-as como se fossem sociedades harmônicas e sem conflitos, incentivando uma saída da sociedade de consumo e uma volta ao contato com a natureza. A segunda, a socioambiental, procura reintegrar o homem à natureza como uma das espécies que a compõem. Vê o meio ambiente como fruto das transformações ocorridas no processo histórico das inter-relações entre sociedade e natureza e os problemas ambientais como problemas sociais que colocam novos desafios ao conhecimento científico e aos limites no próprio

\footnotetext{
${ }^{3}$ Educação Ambiental: Curso básico a distância: educação e educação ambiental II.Coordenação-Geral: Ana Lúcia Tostes de Aquino Leite e Naná Mininni- Medina. Brasíla: MMA, $2^{\text {a }}$ edição, 2001.Volume I, p.58-63.
} 
homem. Quando embasados por essa vertente, educadores procuram reconhecer o aporte essencial das distintas culturas e o resgate dos conhecimentos e técnicas tradicionais em relação ao aproveitamento dos recursos naturais.

Sem arriscar polarizar concepções filosóficas de educação ambiental, cumpre ressaltar que um processo educativo responsável e com objetivos claros voltados para um desenvolvimento sustentável deve partir das representações sociais de meio ambiente e da cultura das pessoas envolvidas na ação pedagógica. Seus pressupostos basear-se-ão em um ideário participativo e democrático, desmistificando, muitas vezes, concepções filosóficas utilizadas com objetivos escusos.

"Cabe acrescentar que a generalização da categoria humanidade como perversa possibilita o uso ideológico da questão ambiental, tirando o foco da análise da estrutura da sociedade e colocando a responsabilidade única e exclusivamente no indivíduo e numa tendência humana instintiva de destruição (naturalmente mau). É por isso que, por exemplo, os programas ambientais com componentes educativos e de ação comunitária, governamentais ou nãogovernamentais tendem a trabalhar exclusivamente os aspectos comportamental e moral. Não se pode negar que essa dimensão ideocultural é também um aspecto importante; porém não é o único nem o determinante, devendo vir associado às mudanças estruturais, assegurando uma sociedade sustentável nas múltiplas dimensões que compõem a vida." (Loureiro, 2000, p.21)

Para Reigota (2001), uma abordagem voltada para a participação do cidadão na elaboração de alternativas ambientalistas, tanto na micropolítica das ações cotidianas, como na macropolítica da nova ordem mundial, exige deste a prática e o aprendizado do diálogo entre gerações, culturas e hábitos diferentes.

Assim, a educação ambiental deve se desvincular das amarras puramente biológicas ou extremamente políticas a fim de proporcionar às pessoas envolvidas no processo pedagógico a oportunidade de ampliar seu leque de participação cidadã. 


\section{2- Interpretação ambiental}

Considera-se a interpretação ambiental como uma atividade importante no que diz respeito à conservação de uma área, uma vez que visa expandir a perspectiva de atitude de cada visitante.

"A interpretação ambiental é uma atividade educativa, que visa a revelar significados e relacionamentos pelo uso de objetivos originais, por meio de uma experiência direta e por meios ilustrativos, em vez de uma simples comunicação fatual da informação." (Wearing e Neil, 2002 p.94 apud Tilden, 1977 p.8)

Salvatti, (2000, citando Ham, 1992) conceitua interpretação ambiental como tradução da linguagem técnica de uma ciência natural de forma que as pessoas, em geral, possam facilmente entender o assunto.

Uma interpretação bem sucedida compreende determinados princípios:

"As pessoas aprendem melhor quando ativamente envolvidas no processo de aprendizado;

As pessoas aprendem melhor quando usam os sentidos adequadamente. .Reconhece-se que, de modo geral, as os seres humanos retêm aproximadamente $10 \%$ do que escutam, $30 \%$ do que lêem, $50 \%$ do que vêem e $90 \%$ do que fazem;

Os insights constituem as experiências mais memoráveis, já que despertam o estímulo e o crescimento;

$O$ aprendizado requer atividade por parte de quem aprende; processo produz mais efeitos quando o indivíduo se conscientiza da utilidade do conhecimento que lhe está sendo repassado;" (Wearing e Neil 2002,p.101 citando Lewin, 1980.) 
Salvatti (2000), em artigo sobre interpretação da natureza, disponível na internet, aborda tanto as etapas de um plano de interpretação ambiental, como os métodos e técnicas para seu desenvolvimento. Consideram-se as qualidades do intérprete outro fator importante no processo fundamental para entender-se como se realizar esta atividade, favorecendo a conservação do ambiente.

Constituem etapas de um plano de interpretação em Unidades de Conservação as seguintes ações:

- Determinação de objetivos;

- Promoção de um inventário interpretativo;

- Seleção dos temas a serem interpretados;

- Identificação das facilidades e os serviços disponíveis para se promover a interpretação;

- Identificação da demanda;

- Análise das alternativas de uso da área;

- Desenvolvimento do plano e sua implementação de forma gradual, seqüencial e contínua;

- Revisão e monitoramento freqüente.

A interpretação ambiental deve caracterizar-se como uma atividade :

- amena e voltada ao entretenimento;

- pertinente e pessoal ;

- organizada;

- dotada de um tema central ou um de objetivo a ser alcançado;

- incentivadora de participação;

- provocadora e questionadora em relação ao visitante;

- bem-humorada.

Em mesmo artigo, segundo Salvatti, ( ibidem apud Silva, 1996), pode-se sugerir como técnicas de interpretação aplicáveis a qualquer tipo de trabalho:

- A conversa deve ser orientada a não fugir do tema; 
- A atmosfera das apresentações deve ter um tom pessoal do guia;

- O aproveitamento do tempo disponível, proporcionando ao visitante um tempo a sós com a natureza para poder apreciá-la como bem quiser.

- A presença do guia deve contemplar o campo de visão de todos visitantes.

Por fim Salvatti (ibdem) diz como proceder, visando-se interpretar melhor a natureza, ao lembrar que, além das características técnicas e profissionais que se exigem do guia / condutor de ecoturismo, este deve:

- Conhecer a área e seu entorno;

- Conhecer o visitante e adaptar-se ao seu perfil;

- Saber terminar uma conversa ou palestra de maneira educada;

- Ser sempre animado ,criativo e gentil;

- Conhecer-se e ser seguro de si mesmo;

- Tratar todos com igualdade;

- Manter boas relações com todos.

Assim, pode-se perceber mais uma vez a importância da educação na atividade ecoturística. Ao assumir o papel de intérprete, exige-se do guia uma boa formação, haja vista a interpretação ambiental abarcar muito mais que a simples transmissão de informações para 0 visitante. $O$ bom desempenho da atividade dependerá da criatividade e da segurança do profissional em ecoturismo ao conduzir o processo, que visa à mediação da construção do conhecimento . 


\section{3- O papel do guia:}

Mesmo que a relação entre o guia e o visitante de áreas naturais ocorra de forma breve, ela se carrega de significados. Deve-se valorizar e respeitar os conhecimentos do guia advindos de sua cultura, da formação técnica e da vivência profissional em ecoturismo, pois tudo isso se coloca em contato com um novo universo trazido pelos turistas que também já viveram experiências diferenciadas.

O guia assume um papel não só de fomentador de educação ambiental como também de educador ambiental e deve preparar-se para o dissenso, tanto defendendo com firmeza suas teses, como respeitando as alheias.

"O ecoturismo permite que a Educação Ambiental seja trabalhada de modo que o visitante tenha oportunidade de vivenciar suas próprias experiências, questionar-se sobre as coisas e buscar respostas à estas questões. Neste sentido, o guia / condutor de ecoturismo deve procurar levar o visitante a questionar-se, provocando-o e estimulando-o a reflexões e valorizando os conhecimentos prévios do visitante buscando a sua participação." ( SALVATTI, 2000, em artigo disponível na internet.)

Considerando-se que o guia de turismo na maioria das vezes sequer obteve a formação básica, os cursos de formação devem agir sobretudo como um estimulador para que ele continue seus estudos. Reconhecendo-se o guia como um possível educador, não se pode pensar que esforços fragmentados atuem efetivamente. Consideram-se ineficientes os pequenos "treinamentos" pois este termo remete a uma concepção behaviorista de aprendizagem, baseada em estímulos e respostas. O papel desse profissional, no projeto ecoturístico, deve transcender ao simples repasse de informações a visitantes, oportunizando uma atuação mais ampla junto à comunidade.

Para que o guia assuma um papel de mediador, de estimulador, de provocador na construção do conhecimento, deve-se orientar sua formação por concepções sócio interacionistas, uma vez que estas admitem a aprendizagem, como um processo que considera o homem em sua totalidade e em interação 
com o meio que o cerca. Por isso tratar-se-á, seguir, das principais concepções sócio interacionistas de desenvolvimento humano e de suas respectivas contribuições para a formação desse tipo de profissional. 


\section{4- A FORMAÇÃO DE GUIAS E AS VÁRIAS CONCEPÇÕES DE DESENVOLVIMENTO HUMANO}

Apresentar-se-ão, a seguir, sínteses de trabalhos de vários autores, versando sobre teorias de desenvolvimento humano, fator indiscutível no processo de ensino aprendizagem e portanto, na formação do guia de ecoturismo.

Acredita-se que se procedendo a uma análise diagnóstica dos cursos oferecidos para formação de guias e/ou condutores de visitantes, perceber-se-á facilmente que o processo apresenta inúmeros problemas, tais como:

- Deficiência financeira: muitos cursos de condutores em pequenas cidades acontecem sem o menor apoio financeiro das prefeituras e instituições ligadas ao turismo, devido à falta de planejamento comum nessa atividade;

- Currículo extenso e centralizado: esses cursos geralmente envolvem muitas informações de extrema importância, mas que trabalhadas a curto prazo, dificultam seu aprendizado;

- Condições desfavoráveis para o empreendimento: falta o apoio logístico para realização dos cursos e nem sempre se remuneram os professores, que trabalham, seja visando contribuir com o desenvolvimento do turismo em sua cidade, seja por se sensibilizarem com a causa ambientalista.;

- Conceito tradicional de aprendizagem e de método de trabalho: o estudante coloca a mera reprodução de conhecimentos como sua atividade predominante, evidenciando uma atitude passiva.

Cursos de formação de guias e/ ou condutores de visitantes com tais problemas formam um ciclo vicioso onde o aluno, futuro guia, desenvolve uma concepção de que se deve transmitir o conhecimento de "cima para baixo", reduzindo-se a atividade do guia a de um mero transmissor de informações elaboradas pelo mestre ou simplesmente decoradas com auxílio de apostilas, supervalorizadas em cursos como esses.

Segundo Azevedo (2001), os cursos de formação devem se preocupar com a construção de um ofício novo, em que a tarefa do aprender / 
fazer supere o a simples transmissão de informações. Para isso, necessita-se romper com os limites positivistas, o determinismo newtoniano, o racionalismo e o dogmatismo clássico para conceber-se o conhecimento como uma construção dinâmica, não determinada pela prática social, de forma que, a partir dele, o indivíduo possa interferir na sua realidade, identificando e resolvendo os problemas e desafios colocados pela vida social.

"A partir do rompimento da concepção de homem, de sociedade e de mundo derivada do determinismo científico clássico é que os educadores poderão construir um novo pensamento estruturante do fazer pedagógico, isto é, um novo paradigma educacional. Esse rompimento tornará possível rejuntar a teoria e a prática, a ação e a reflexão, a formação da consciência e a realidade material e cultural." (Azevedo, 2001, p. 53)

A construção de uma proposta de formação de guias que supere esses desafios exige relações simétricas entre os conhecimento de muitas áreas, tais como: sociologia, antropologia, filosofia, biologia e psicologia. $\mathrm{O}$ presente estudo pretende levantar alguns dos aspectos da relação da psicologia do desenvolvimento e educação, ressaltando aqueles que mais dizem respeito à formação de guias. 


\section{1- A Psicologia do Desenvolvimento}

A psicologia causa, sem dúvida, um grande impacto na formação de guias porque trata de questões relativas ao desenvolvimento, à aprendizagem e ao comportamento humano. De acordo com Lima (1990) essa relação, no Brasil, tem-se caracterizado pelo domínio da teoria piagetiana já mais antiga ,para ceder lugar às teorias sociointeracionistas, notadamente a de Vygotsky, acompanhada mais recentemente de um incipiente ressurgir de Wallon.

Em cada um desses momentos, vem-se tratando de forma diferente a cultura, que se transformou num elemento importante para compreender-se $o$ desenvolvimento humano. De acordo com Lima (1990), a partir da expansão do cognitivismo, com o desenvolvimento da cognição social, a antropologia passou a exercer papel importante e duas linhas de desenvolvimento surgem: a psicologia intercultural e a cultura como elemento constitutivo do ser humano.

A psicologia intercultural desenvolveu-se a partir de estudos comparativos de natureza piagetiana, que visavam comprovar igualdade, similitudes e diferenças entre o desenvolvimento de crianças de culturas variadas. Esse processo constituiu-se como importante contribuição nas questões metodológicas da antropologia, devido à sua familiaridade com a diversidade das condições humanas e suas teorias do meio, possibilitando uma pesquisa mais detalhada a esse respeito.

A cultura como elemento constitutivo do ser humano constituiu-se a outra linha de pensamento. Esta busca compreender a dinâmica interna das relações pessoais e a forma como a cultura e a instrumentação local intervêm sobre elas.

Essa discussão recebe significativo suporte teórico de algumas perspectivas de desenvolvimento humano que questionam outras abordagens que, tradicionalmente, não consideram nem o social nem o cultural como relevantes para o desenvolvimento do ser humano. 


\subsubsection{Vygotsky}

A Grande Revolução Soviética determinou a obra de Vygotsky, levando-o a desenvolver uma nova ciência psicológica que substituísse tanto o freudismo, gestaltismo, behaviorismo como outras, consideradas "nova psicologia", como a psicologia empírico-subjetiva, vistas por ele , como "velha psicologia". Desejava-se, a princípio, criar-se uma psicologia que partisse da filosofia do materialismo dialético e histórico, ou seja, uma psicologia marxista.

Vygotsky (1999) diz, que, na época, para construir-se uma psicologia marxista, partindo-se das teses gerais do materialismo dialético, necessitar-seia elaborar uma base metodológica da ciência, capaz de estudar os fatos concretos obtidos por meio de investigadores que mantivessem diferentes posições teóricas. Por isso o autor afirma que:

“... os fundamentos teórico-metodológicos da psicologia marxista deveriam começar a ser elaborados a partir da análise psicológica da atividade prática, laboral do homem, a partir de posições marxistas. É precisamente aí que jazem as leis fundamentais e as unidades iniciais da vida psíquica do homem." (Vygotsky, 1999, p. 428)

A partir desse ponto, desenvolvem-se as bases da teoria históricocultural da evolução da psique, estudadas a partir da análise da atividade prática. Segundo essas idéias, nos processos psíquicos do homem, existe a razão entregue a si mesma e a razão armada de instrumentos e meios auxiliares, da mesma forma que, na atividade prática, existe a simples mão e a mão armada de ferramentas e elementos auxiliares. Em ambas as situações, Vygotsky salienta a importância decisiva no segundo nível, chamado por ele de cultural.

A partir dessa hipótese, o autor relaciona as funções psíquicas inferiores à base dos processos psíquicos naturais e as superiores às culturais. Dessa forma o estudioso reconhece o psíquico como um sistema não-fechado, estruturado de forma complexa e aberto ao mundo exterior. Além disso, segundo ele, essas funções psíquicas (culturais e superiores) constituem-se formações históricas e portanto, deve-se analisá-las no nível ontogenético, 
filogenético e patológico, a partir do método de Marx, que consiste na atividade laboral do homem com a ajuda de instrumentos.

O estudo da história da formação das funções psíquicas superiores na ontogênese e na filogênese como formações constituídas sobre a base de funções psíquicas elementares, que atuam de forma mediada, empregando instrumentos psicológicos, converteu-se, então, no tema central das investigações de Vygotsky. De acordo com ele, esses fatores constituiriam criações artificiais da humanidade e elementos da cultura, dirigidos inicialmente para fora e somente depois para o ser humano, num processo de interiorização.

Ao estudar a relação entre o pensamento e a linguagem, Vygotsky (1999) também investiga o processo histórico-genético, concluindo que as raízes genéticas do pensamento e da linguagem humana diferenciam-se e só se cruzam em determinada etapa.

"A linguagem é um instrumento psicológico que age de forma mediada no estágio precoce do pensamento (por estágio precoce do pensamento subentendia-se a atividade prática). Como resultado desse caráter mediado, se forma 0 pensamento verbal." (Vygotsky,1999,p.456.)

Contrário ao pensamento de Piaget, Vygotsky encontra uma manifestação da associabilidade original inerente na linguagem egocênctrica, que vai desaparecendo à medida que ela se socializa. Acrescenta que a linguagem egocêntrica constitui-se como social desde a sua origem e não desaparece, mas converte-se em linguagem interior. Ao mesmo tempo, essa capacidade representa, segundo o estudioso russo, um importante instrumento do pensamento resultante da atividade da criança quando esta se utiliza de objetos

Esses estudos levaram o autor a afirmar que os conceitos e os significados das palavras passam por várias fases de desenvolvimento como pseudoconceitos e conceito, e ainda o sincretismo, que se constituem generalizações complexas. Os conceitos dividem-se em cotidianos e científicos. Os primeiros representam generalizações de coisas e os segundos, de pensamentos. Ao coordenar esses conceitos, Vygotsky conclui que o grau 
de assimilação dos conceitos cotidianos mostra o nível de desenvolvimento atual do sujeito, ao passo que o de conceitos científicos corresponde a sua ZDP (Zona de Desenvolvimento Proximal).

O autor afirma ainda que, à medida que os conceitos cotidianos desenvolvem-se espontaneamente, a consciência do indivíduo assimila os conceitos científicos durante a instrução. O ensino desempenha, assim, um enorme e decisivo papel no progresso intelectual do indivíduo, e por isso reconhece-se o seu valor apenas se ele acompanha o desenvolvimento da pessoa.

\section{Vigotsky e a formação de guias de visitantes}

A teoria de Vigotsky privilegia a influência sociocultural no desenvolvimento humano, ao relacionar a formação de guias ao processo de aprendizagem e especificamente, ao processo de construção de conhecimentos, que poderá tornar-se mais efetivo caso se considere a realidade do educando, cuja exploração servirá de ponto de partida para que se adquiram novos conhecimentos. Deve-se atentar para as diferenças culturais de cada guia e os diferentes papéis desempenhados por eles em sua comunidade, como afirma o autor, que considera a cultura fator determinante para o desenvolvimento, mas também analisa o ensino como algo salutar no aprimoramento e na aquisição de conhecimento. Assim a formação do guia deve caracterizar-se pela mediação entre esse profissional, o conhecimento formal adquirido e suas vivências sócio- culturais.

Desse modo, não se deve promover uma formação baseada na simples "transmissão de conteúdos" muito menos aqueles descontextualizados, cabendo ao formador mediar a construção do conhecimento. 


\subsubsection{Wallon}

Wallon é um psicólogo especialista na infância e, como Piaget, esforça-se em ultrapassar a contradição de duas teorias: a do homúnculo, em que a criança caracteriza-se como uma redução do adulto e a das mentalidades distintas. Ele acreditava que, confrontando-se a criança com o adulto, poder-se-ia revelar, de etapa em etapa, o verdadeiro plano de sua vida mental. Assim, ao analisar-se a gênese real de uma criança, descobrir-se-ia o homem.

Em "A Evolução do Pensamento da Criança" (1968), o autor afirma que costuma-se impor à criança o mundo dos adultos, daí resultando, em cada época, uma certa uniformidade de formação mental. Mas isso não significa que o adulto possa exigir da criança senão aquilo que ele próprio the transmite. Segundo ele, a maneira como a criança assimila o mundo pode não apresentar nenhuma semelhança com a forma como o adulto o utiliza, uma vez que aquela possui disponibilidades psíquicas que este manifestaria de outro modo, o que leva Wallon a questionar:

"Com a ajuda da civilização, não estarão em potência na criança outros desenvolvimentos da razão e da sensibilidade?" (Wallon, 1968, p. 32)

No final da primeira parte de seu livro, o autor discute os fatores do desenvolvimento psíquico. Como teórico interacionista, acredita que as necessidades do organismo e as exigências sociais constituem-se os dois pólos entre os quais se desenvolve a atividade do homem. Afirma que não consegue dissociar o biológico do social, uma vez que estes the parecem estreitamente complementares no homem, desde o seu nascimento e ainda considera impossível encarar a vida psíquica sem se reconhecer como esses dois fatores agem nas relações recíprocas. Portanto, ao mesmo tempo que em cada etapa de vida do indivíduo acontece um equilíbrio estável entre as possibilidades atuais e as condições de vida correspondentes, ocorrem mudanças cujas causas orgânicas podem interferir na relação funcional.

Ao nascer, o indivíduo não pode subsistir por si próprio porque seus órgaos não se desenvolveram suficientemente. Assim, a única forma de sobrevivência da criança, num primeiro momento, consiste em relacionar-se 
com aqueles que a rodeiam, extravasando suas reações e suscitando naqueles que o cercam comportamentos proveitosos ao seu desenvolvimento. A esse respeito Wallon, afirma que quanto maiores forem as oportunidades colocadas diante da criança, mais dúvidas podem advir num primeiro momento, trazendo resultados positivos e acarretando um progresso maior.

O autor também discute as atividades da criança e a sua evolução mental. Afirma que entre os traços psicofisiológicos que marcam cada etapa do seu desenvolvimento, inclui-se o gênero da atividade a que esta se entrega o que acarreta um maior evolução mental. De acordo com o estudioso, existem diversos fatores que contribuem para a evolução mental como: os estimulantes, os interesses, as funções e as alternativas apresentadas à criança.

Segundo Wallon (1968), a todo instante gestos induzem a sua repetição, suscitando um novo gesto destinado a reproduzi-lo e muitas vezes a modificá-lo ao longo de séries de variações sistemáticas, num encadeamento mútuo dos efeitos e dos atos. Ele acrescenta que esse processo pode acarretar reações tanto imprevisíveis e inopinadas como esperadas e previstas. Medemse esses atos, tanto pelas mudanças subjetivas como pelas objetivas que provocam ou procuram provocar. Para unir os dois termos, Wallon afirma ainda que isso ocorre em decorrência do fator afetivo, primordial no desenvolvimento.

Continuando, o autor fala sobre o jogo, outra atividade importante para evolução mental e afirma que este se constitui, antes de tudo, em lazer. Como a criança ainda não trabalha, o jogo confunde-se facilmente com toda a sua atividade, enquanto esta se mantém espontânea e ainda não se submete a uma educação formal. A esse respeito Wallon afirma que:

"O jogo é, sem dúvida, uma infração às disciplinas ou às tarefas que a todo o homem impõem as necessidades práticas da sua existência, a preocupação da sua situação, da sua personagem. Mas, bem longe de ser a negação ou renúncia dessas necessidades, o jogo pressupõe-nas. É em relação a elas que é apreciado como período de repouso e também como recobrar de energias, porque, livre das exigências de tais atividades, o jogo é o livre inventário e a 
manifestação destas ou aquelas disponibilidades funcionais." (Wallon, 1968, p. 80)

Desta forma, o jogo pode momentaneamente libertar o sujeito das funções automatizadas pelo cotidiano, tornadas escravas pelo seu uso habitual, demonstrando-se assim que este evolui entre oposições e, ao superá-las, ele se realiza.

A partir de 6 anos, Wallon acha possível retirar a criança das ocupações espontâneas, visando integrá-las às disciplinas da escola, o que pressupõe, inevitavelmente, um correspondente poder de autodisciplina. Afirma ainda que o cotidiano da escola deve considerar as atividades exteriores, que mudam de acordo com as circunstâncias .

Para Wallon o desenvolvimento da criança não se promove por uma simples adição de progressos que seguem sempre no mesmo sentido. Colocam-se as diferentes idades como fases de orientação alternativamente centrípeta e centrífuga, voltadas para a progressiva edificação do próprio indivíduo ou para o estabelecimento das suas relações com o exterior, para a assimilação ou para a diferenciação funcional e adaptação objetiva. Analisando-se os períodos, pode-se não só encontrar componentes mais elementares que expliquem este vaivém, como também reconhecer, em cada fase, uma ambivalência que oportuniza exercer-se tanto o papel de íntima elaboração, como o de reação ao meio.

Assim se escalonam, desde as funções puramente fisiológicas ou elementares até às funções de grande multiplicidade nas suas condições, de grande complexidade nas suas conseqüências, cuja alternância provoca quer o crescimento próprio, íntimo do indivíduo, quer a extensão dos seus meios e objetivos ao mundo exterior .Esse processo repete-se de forma idêntica e os resultados das mudanças cotidianas assemellham-se a um ciclo vicioso. Só a longo prazo vai-se se sentir a transformação que pode aparecer repentinamente apenas na puberdade. Assim a criança desenvolve-se, evidenciando comportamentos que se modificam de idade para idade.

Wallon denunciou que consiste num erro o fato de simplesmente se contraporem os defeitos e os vícios da pedagogia tradicional às doutrinas da nova educação, haja vista estes não ocorrerem da mesma forma nos 
reformadores. Afirma ainda que a nova educação prejudica-se, ao não adaptar o sujeito ao meio em que ele vive. Embora apresente falhas, o processo permitiu que se levantassem os problemas, enquanto se espera conhecer mais a respeito da criança e do universo escola.

O autor acrescenta que o conhecimento da psicologia da criança permite compreender que não se pode nem apagar o mestre, nem suprimir-se o esforço puramente intelectual, nem se contar apenas com a espontaneidade do educando, uma vez que a criança, de acordo com o estudioso, necessita da intervenção do adulto e das pressões do meio para afirmar-se como pessoa e desenvolver todas as suas capacidades.

Wallon utilizou-se do método materialismo dialético, consagrandoIhe numerosos comentários. Não procedeu de forma dedutiva a partir de um dogma, de uma ideologia e por isso mesmo inovou. Seu pensamento se impõe e poderá se impor vez mais, mesmo entre aqueles que não aceitam o marxismo. Segundo o autor, os fatos devidamente estabelecidos sobrepujam em valor os argumentos de autoridade.

\section{Wallon e a formação de guias de visitantes}

Mesmo se considerando Wallon um psicólogo da infância, pode-se identificar em sua teoria contribuições para a formação de guias em ecoturismo, uma vez que ele não dissocia o biológico do social e acredita nas influências do meio, ao reconhecer o homem como ser social por natureza. Por isso, deve-se contemplar essa abordagem no processo de formação de um guia, já que para agir na natureza, necessita-se que o profissional do ecoturismo atente para o seu papel diante dela, reconhecendo-se como ser social e biológico. Uma vez que além de constituir ele mesmo parte da natureza, pode influenciar nos modos de pensar e agir dos visitantes diante do meio natural.

A afetividade acarreta determinadas mudanças, constituindo-se, por isso, outro ponto de extrema importância no que se refere à formação do guia e sua posterior atuação. Se este puder reconhecer o ambiente natural como algo inerente à sua existência e não pensar somente na sua exploração, mudar-se-á a sua relação afetiva em relação a ele e consequentemente a sua maneira de agir. 
Enfim, Wallon propõe uma concepção dialética de educação que pressupõe uma articulação indissolúvel entre teoria e prática. Assim urge organizar cursos de formação onde teoria e prática sejam contempladas com a mesma importância. 


\subsubsection{Bronfenbrenner}

De acordo com Bronfenbrenner (1996), explica-se o comportamento das pessoas pelas interações a ambientes passados e presentes. Portanto, antes de mudar aqueles, precisa-se transformar estes. Essa sugestão acarreta necessariamente uma reorientação no modo de encarar os processos psicológicos, passando-se a tratá-los como propriedades de sistemas, dos quais o indivíduo constitui-se apenas um dos elementos.

Bronfenbrenner, discute muito a teoria de Vygotsky, mas encontra em Kurt Lewin uma contribuição mais sólida para seu trabalho. Este afirma que o comportamento advém das relações entre o meio ambiente e o indivíduo, representando-o da seguinte forma: $B=f(P . E)$ onde $O B$ representa $O$ comportamento, o f representa a função/processo, $O P$, pessoa e $\circ \mathrm{E}$, ambiente. $O$ estudioso russo, em sua teoria, muda $B$ (comportamento) por $D$ (desenvolvimento). A partir disso, afirma que, em matéria de desenvolvimento, deve-se estudar como o indivíduo se transforma ao interagir com o meio, como se constitui o ambiente onde ocorreu essa transformação e como acontece essa interação homem-meio à medida em que o indivíduo se desenvolve. $O$ autor busca, assim, entender o processo ( $\mathrm{f}$ ) que conduz à mudança.

Lewin estudou dois modelos mais amplos do desenvolvimento: o primeiro, de classe teórica ou de categoria, engloba os estudos de endereço social, nicho ecológico, atributos pessoais e contexto pessoal; o segundo, de campo teórico ou dinâmico, engloba estudos do microssistema, da pessoa, do contexto e da pessoa-contexto.

No modelo de classe teórica, o estudo de endereço social não analisa razões dos resultados diferentes e não se interessa por razões individuais. O seu foco consiste em comparar contextos com o auxílio do estudo de nicho ecológico, que também contribui para isso, embora num nível um pouco mais complexo. Essa teoria não se interessa pelo aspecto do indivíduo nem por que ele acontece. O estudo de atributos pessoais não leva em conta contextos ou grupos, mas as características do indivíduo. Desta forma, a pesquisa em laboratório com todas as variáveis controladas aparece como situação ideal. Não se trabalha, portanto, com o estudo longitudinal, mas 
com o transversal e o estudo de contexto pessoal analisa a pessoa e o ambiente, esquecendo-se do processo de desenvolvimento.

O modelo de campo teórico caracteriza-se como mais dinâmico. Nele o estudo do microssistema analisa a pessoa, observando como seus atributos interferem na interação com os outros, ignorando o contexto e não se interessando em constatar diferenças, mas procurando entender por que elas ocorrem. O estudo do contexto apresenta mais complexidade e busca identificar as diferenças, que podem impedir que uma pessoa interaja com outra. Bronfenbrenner considera o modelo de estudo da pessoa-contexto como o melhor deles, pois se preocupa com o processo, os atributos pessoais e o contexto.

Atualmente, Bronfenbrenner ainda inclui nesse último modelo, o tempo, uma vez que, ao analisar-se o processo, necessariamente envolve-se tempo. Propõe, então uma forma de incluir o tempo diferentemente dos estudos transversais, que não consideram o desenvolvimento. Por outro lado, ocorre o modelo que admite estudos longitudinais e leva em conta o tempo histórico. O autor ainda divide esses estudos em trans-sectional, short-term (termo curto) longitudinal e de curso de vida.

A proposta de Bronfenbrenner, portanto, envolve PPCT - pessoa, processo, contexto e tempo. A respeito da pessoa, o autor analisa as características de seus estímulos, diante das pessoas ao seu redor e as características instigativas do desenvolvimento. Estas causam maior impacto no meio, mostrando como a forma de o sujeito se comportar modifica o ambiente.

Bronfenbrenner analisa os processos proximais, que ocorrem próximos dentro de um microssistema. Segundo o autor, isso constitui o ponto principal do desenvolvimento e ocorre progressivamente a partir das interações com outras pessoas, objetos e símbolos. Esses processos proximais variam tanto em função das características da pessoa e do ambiente, como da natureza do interesse individual. Portanto processos proximais constituem-se interações recíprocas e regulares que ocorrem dentro de um ambiente, durante um certo tempo e aumenta sua complexidade progressivamente. 
Bronfenbrenner divide o contexto em quatro camadas. Em primeiro lugar, aparece o microssistema, que engloba as camadas mais próximas do ambiente do indivíduo, em cujo processo de desenvolvimento ele pode interagir com outras e engajar-se em atividades.( Por exemplo a relação estabelecida entre o guia e o visitante em uma determinada trilha). Em segundo, ocorre o mesossistema que estabelece ligações entre dois ou mais microssistemas. (Por exemplo a troca de experiências entre vários grupos distintos de visitantes e comunidades visitadas). Em terceiro, figura o exossistema, que abrange as camadas mais distantes nas quais a pessoa não se insere, mas influirá no seu desenvolvimento. ( No caso do guia ele deve seguir algumas orientações determinadas pela administração do parque para que a guiagem possa acontecer naquele local). Por último, constata-se o macrossistema, que se constitui de crenças, valores, práticas, instituições de uma cultura particular, ou subcultura de uma cultura e que produz apenas efeito indireto. ( Para visitantes o fato de estarem visitando uma outra cultura com modos, valores e crenças diferenciadas poderá influenciar alguns de seus hábitos durante o período de visita).

Em relação ao tempo, Bronfenbrenner divide-o em: microtempo, mesotempo e macrotempo e representa sua proposta, utilizando-se do seguinte diagrama:

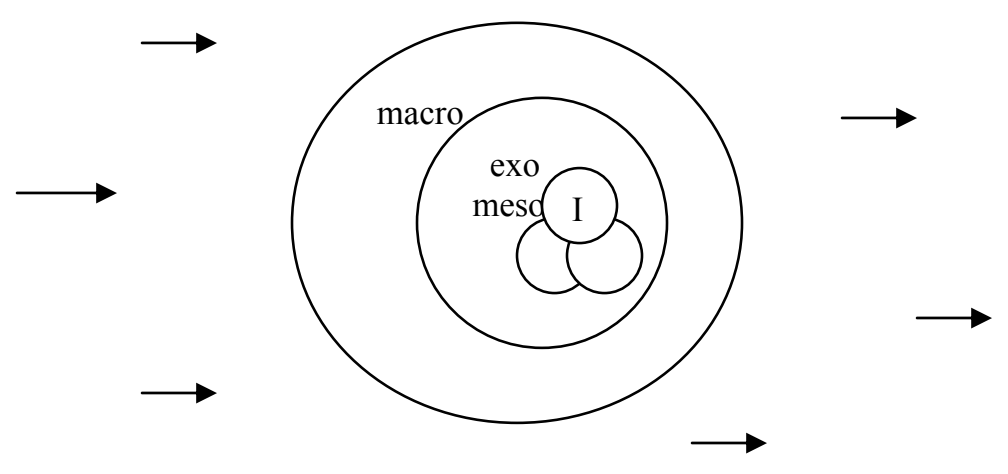

Nesse diagrama I representa o indivíduo e as setas, a passagem do tempo. 
Bronfenbrenner acredita que o indivíduo nasce com a propensão a uma determinada característica. Pode-se mudá-la, dentro de um pequeno limite, caso o meio concorra para isso, porque assim como este interage com a pessoa, assim ela interage com ele. Isso ocorre em um microssistema constituído por pessoas, símbolos ou objetos, com as características do ambiente interferindo nas interações. Percebe-se assim que a teoria PPCT de Bronfenbrenner vê a realidade numa perspectiva sistêmica, com o indivíduo interagindo com o meio.

\section{Bronfenbrenner e a formação de guias de visitantes}

Cabe observar o fato de Bronfenbrenner acreditar que o homem se transforma quando interage com o meio. Assim um curso de formação de guias, se atento a isso, procurará construir, junto ao profissional de turismo, propostas de guiagem ou interpretação que permitam ao visitante interagir com o meio, advindo daí a mudança de comportamento.

Bronfenbrenner crê que o desenvolvimento ocorre quando o indivíduo interage com outras pessoas, objetos e o ambiente. Assim uma formação que possibilite maior número de interações possíveis, bem como trocas de experiências contribuiria muito para a formação de um guia cuidadoso, interessado e atualizado, capaz de proporcionar aos visitantes experiências ricas junto à natureza. 


\subsubsection{Valsiner}

Valsiner (1997) apresenta uma perspectiva teórica de desenvolvimento humano que visa explicar uma estrutura dinâmica de limites como um dos mecanismos desse processo.

O autor afirma que as diferentes disciplinas científicas, inclusive a psicologia, constituem-se semioticamente, por meio de um complexo processo narrativo simultâneo, dentro de um sistema social, em um dado tempo e espaço. A compreensão do significado de psicologia do desenvolvimento, de acordo com ele, resulta portanto do desenvolvimento de significados semioticamente mediados pela psicologia, emergidos tanto da biologia desenvolvimental como da estrutura institucional social.

Valsiner visa encontrar uma forma de conceituar desenvolvimento, observando o processo cultural no qual este se insere. Afirma, de início, que se define desenvolvimento como uma transformação construtiva, em tempo irreversível, promovendo a interação entre o organismo e o ambiente. Segundo o estudioso, define-se esse processo a partir de Piaget, cujo enfoque na transformação construtiva de estrututras e no conceito de equilibração, gera uma noção sistêmica e um aspecto dinâmico ao desenvolvimento. $O$ autor também se baseou em Vygotsky, que prega tanto a interação organismoambiente, como a irreversibilidade do tempo e a participação ativa da pessoa em seu desenvolvimento. Além disso, Vygotsky conceitua zona de desenvolvimento proximal, como aquela que antecipa as condições futuras capazes de produzir a interação organismo-ambiente.

A esse respeito, Valsiner assume uma natureza semi-indeterminada e irreversível do processo de desenvolvimento, apresentando uma perspectiva de modulação temporal de limites, cujo desenvolvimento acarreta a construção de um sistema hierárquico de estruturas instáveis, guiando o organismo em desenvolvimento num processo de construção do futuro imediato. Explica o conceito de "constraints type feed-forward" (limites que antecipam o futuro) como organizadores temporários do fluxo do desenvolvimento do qual emerge e desaparece o indivíduo. Esses limites flexíveis modulam as direções do processo de desenvolvimento, deixando a construção exata de novas formas 
para acordos negociados obtidos na interação irreversível entre a pessoa e o ambiente.

Em seguida, Valsiner distingue a cultura pessoal e a cultura coletiva. .A pessoa, em sua unicidade pessoal, relaciona-se sempre com um mundo significado culturalmente, uma vez que a cultura coletiva envia mensagens sociais com significados, normas e práticas diárias e o indivíduo constrói o seu sistema semiótico idiossincrático pessoal de símbolos, práticas e objetos (cultura pessoal) a partir dessa cultura coletiva.

No entanto, a cultura pessoal não abrange somente a internalização subjetiva, mas também a sua imediata externalização.

"A atividade da pessoa encontra com o mundo, transforma significados culturais coletivos em um sistema cultural pessoal de sentidos (por meio da internalização) e contribui para a reconstrução de significados pela externalização de seu sistema de sentidos pessoais." (Valsiner, 1997, p. 31)

Valsiner afirma ainda que o desenvolvimento humano, dentro de um contexto cultural coletivo, caminha através de limites que antecipam o futuro, contribuindo para o desenvolvimento humano, ora contínuo, ora descontínuo, estruturado pelos limites de um lado e fluido por outro, pois os estes admitem uma gama de possibilidades, mas somente uma delas se realiza devido à irreversibillidade do tempo da vida real. O autor afirma ainda que sempre ocorrem discrepâncias entre as culturas pessoal e coletiva, uma vez que aquelas esperam transcender às expectativas destas, ao introduzir-lhes novidades pessoais. Essa discrepância, segundo ao autor, energiza o processo desenvolvimental.

Segundo Valsiner, cria-se e mantém-se a cultura coletiva quando se externalizam os sistemas de sentido pessoais de diferentes indivíduos, transformando-a numa entidade relativamente estável e de origem coletiva. Ele afirma, no entanto, que a cultura coletiva caracteriza-se pela sua indeterminância ontológica, pois não se pode descrevê-la como algo que existe, já que constantemente ela se reconstrói num processo coletivo e com um variado grupo de pessoas. 
Nesse processo, segundo o autor, a cultura coletiva garante um amplo e inescapável campo de acesso aos sistemas de significados culturais codificados, influindo tanto no mundo diário do indivíduo, que este não pode evitar o contato com o mundo cultural organizado coletivamente.

Valsiner discute as limitações duais, que juntam os limites de ação e os limites intrapsicológicos da cultura pessoal. Segundo o autor, a pessoa pode confrontar os limites gerais da cultura coletiva com os limites pessoais culturais recriados internamente, também chamados por Valsiner de autolimitações intrapsicológicas. Dessa forma, internalizam-se os significados culturais coletivos de forma que os componentes afetivos e cognitivos da idéia complexa entrelacem-se, não só eliminando os modos pensar e de agir indesejáveis, como também motivando as pessoas a fazê-lo de forma desejável.

O estudioso acrescenta que essas limitações redundantes acarretam o desenvolvimento humano superlimitado tanto no domínio da ação como no da reflexão. Entretanto, isso se constitui um processo dinâmico, em que episódios durante os quais se observam extensão dos limites menor ou indeterminada, interpassam aqueles de superlimitação.

\section{Valsiner e a formação de guias de visitantes}

A formação de guias, nesse caso, pode utilizar-se das contribuições de Valsiner quando este define o desenvolvimento como uma transformação construtiva. A partir daí, percebe-se o processo de aquisição de conhecimento como uma construção e não como apreensão apenas. Por isso deve-se estimular o guia a formular o conhecimento em suas relações com o grupo.

Pode-se deduzir, assim, que reconhecer as discrepâncias entre as culturas pessoais e coletivas pode contribuir muito para o processo desenvolvimental, daí a importância de respeitar-se e discutir-se esse fato durante o processo de formação do guia de ecoturismo. 


\subsubsection{Baltes}

Baltes (1979) apresenta a Teoria do Curso de Vida, muito compatível com os teóricos anteriormente citados, embora enfatize o desenvolvimento humano do nascimento até a morte, principalmente na fase adulta e no envelhecimento. Segundo ele, essa constitui-se uma nova tendência na psicologia e aparece somente agora devido ao envelhecimento dos pesquisadores e da população e, principalmente, aos vários estereótipos sobre a aprendizagem de adultos e idosos.

Sua teoria nasce a partir da geontologia (estudo da idade adulta) e do enfoque sociocultural, mostrando o ser humano num contexto maior e numa perspectiva sistêmica. $\mathrm{O}$ autor sugere ainda um estudo da vida que englobe tanto o desenvolvimento de mudanças, como as constâncias na ontogênese enumerados a seguir:

1. A ontogênese consitui-se um processo para a vida inteira tanto contínuo, como inovativo, dialético e sistêmico.

2. O desenvolvimento multidirecional, diverso e pluralista, ocorre em vários níveis, de várias maneiras, tanto intra-individual como inter-individual, o que, de acordo com o autor, possibilita ganhar-se e perder-se no processo de desenvolvimento. Essa perspectiva vê o desenvolvimento como não-linear e considera que mudanças podem ocorrer não só na estrutura psicológica como também nas funções biológicas do indivíduo.

3. O desenvolvimento representa um processo de ganhos e perdas e continua sempre, com exceção dos casos de doenças ou anomalias e depende do curso de vida individual. Baltes apresenta em seu estudo científico e na avaliação a noção de corte - pessoas que nasceram no mesmo tempo histórico e possuem uma visão cultural, social e econômica específica - exigindo, no estudo do desenvolvimento, um caráter longitudinal e contextual.

4. O desenvolvimento apresenta plasticidade, podendo modificar-se em função dos limites desta. Estes representam o potencial de mudança da capacidade adaptativa e apresentam dois aspectos: flexibilidade e resistência. De acordo com Baltes, no processo de desenvolvimento, busca-se um equilíbrio entre essas duas características, pois, se por um lado a resistência constitui-se fator muito importante para a preservação da identidade, não pode 
se pode deixá-la aumentar muito, pois nesse caso o indivíduo perderia a flexibilidade necessária. Esse conceito advém da neurologia e varia de acordo com as pessoas e com a fase de desenvolvimento em que se encontram. No entanto, a psicologia do desenvolvimento, diferentemente da neurologia, não admite a percepção de que quanto mais velho, menor a plasticidade.

O contexto sociocultural também exerce um papel fundamental nesse processo. De acordo com Baltes, a plasticidade caracteriza-se como cultural e apresenta limites físicos, biológicos e socioculturais. Daí se conceituar reserva como capacidade de enfrentar dificuldade, descobrir coisas novas e reagir às mudanças rápidas. De acordo com o autor, os indivíduos possuem diferentes níveis de reserva, dependendo da história social e cultural individual.

5. O conceito de que o desenvolvimento ocorre num nicho histórico apresenta-se menos amplo que o de contexto e refere-se aos elementos já colhidos e internalizados, enquanto o indivíduo interagia com o ambiente.

6. O desenvolvimento contextualiza-se por três sistemas: o primeiro, normativo, envolve as etapas de desenvolvimento biológico, cognitivo e social que não causam o desenvolvimento, mas acontecem nele. O segundo, nãonormativo, pertence à pessoa, caracteriza-se como idiossincrático, individual e histórico.

7. O desenvolvimento humano, a cuja compreensão se pretende chegar, caracteriza-se como multidisciplinar, ao englobar várias áreas como a antropologia, a sociologia, a biologia, a psicologia e a educação.

\section{Baltes e a formação de guias de visitantes}

A teoria de Baltes revela-se de extrema importância para a formação de guias em ecoturismo, porque estuda o adulto e estes constituem a maioria dos profissionais dessa área. Propõe um equilíbrio entre a resistência e a flexibilidade, daí se podendo deduzir que os formadores de guias em ecoturismo devem atentar para tipo de clientela que vai enfrentar, trabalhando de maneira a quebrar resistências. Caso se trate o conhecimento de maneira multidisciplinar e contextualizada, ocorrerá o desenvolvimento efetivo.

Enfim, cabe lembrar que uma formação profissional de qualquer natureza deve contar com contribuições das mais diversas áreas do 
conhecimento, visto que a forma fragmentada e linear como vem se tratando o conhecimento acaba repercutindo de maneira negativa nesse processo. 


\subsection{Pressupostos teóricos para a formação de guias}

Após a análise da teoria de cada estudioso apresentado e de algumas contribuições destas para a formação de guias de visitantes pode-se destacar alguns pressupostos teóricos que possivelmente poderão fundamentar uma proposta para formação de guias em ecoturismo, tais como:

1. Processo de ensino - aprendizagem: deve ser capaz de levar o guia a desenvolver a habilidade de pensar formas de acesso e apropriação do conhecimento, proporcionando uma autonomia do educando ao longo de sua vida profissional, para tanto é preciso considerar como os futuros guias de visitantes se apropriam e constroem seus conhecimentos, suas características pessoais, suas experiências de vida e profissionais. $O$ conhecimento deve ser rico de significado para o aluno, e elaborado por meio de questionamentos, discussões e troca de experiências.

2. Relação professor aluno: o professor tem o importante papel de mediador e de fomentador da aprendizagem e do desenvolvimento individual do aluno, o aluno por sua vez nesse processo é ativo e interativo. Quando se tem uma relação interativa entre professor e aluno ambos devem respeitar diferenças e contradições, utilizando o erro como fonte de novas experiências.

3. O desenvolvimento: este deve estar intimamente ligado a produção coletiva, ao contexto sócio- cultural dos alunos e a afetividade que é um fator determinante para um melhor desenvolvimento do educando.

4. O programa de curso: deve oportunizar experiências educativas variadas que permitam ao guia estabelecer diferentes interações, tanto com a teoria quanto com a prática. A relação teoria $\mathrm{e}$ prática não deve ser fragmentada, proporcionando ao educando segurança e melhor entendimento do conteúdo.

5. A relação homem / natureza / cultura: O ser humano deve ser reconhecido como parte integrante da natureza e como tal 
responsável por suas intervenções, a cultura nesse processo também passa a fazer parte da natureza reconhecendo-se assim a necessidade de uma interação harmônica nessa relação que é bastante complexa.

6. Construção do conhecimento: considerar os futuros guias de visitantes como sujeitos ativos de seu processo de construção de conhecimento significa considerar suas representações, conhecimentos e pontos de vista, assim o processo de construção pode ser ampliado à medida que se propõe a criação de situações problemas que os confrontem com obstáculos que exijam sua superação, bem como situações didáticas que proporcionem reflexão, experimentação e ação. 


\section{5- CONSIDERAÇÕES FINAIS}

Primeiramente deve-se reconhecer o termo ecoturismo como bastante complexo, revestido de um cárater educativo de extrema importância para a conservação da natureza e que liga estreitamente a educação ambiental à atividade ecoturística, assumindo várias abordagens que contemplam diferentes posturas filosóficas. Assim a formação de guias deve privilegiar a mediação e a construção do conhecimento, selecionando as diferentes representações sociais referentes ao meio ambiente. Interagindo com o meio natural, as pessoas e sua cultura, o guia conseguirá subsídios para diferenciar tais abordagens, identificando neles aspectos positivos e negativos, podendo assumir uma postura realmente efetiva, visando à sustentabilidade ecológica, cultural e econômica do processo.

O guia poderá assumir diferentes papéis na sociedade, dependendo de sua formação e experiências acumuladas. $O$ modo como se planejou $O$ ecoturismo em sua região constituir-se-á fator importante para definir seu papel perante a comunidade, podendo o profissional assumir-se como um mero transmissor de informações, um intérprete ou até proceder como um educador ambiental, cuja responsabilidade ultrapassa as esferas da guiagem.

Quanto às contribuições da psicologia do desenvolvimento para formação de guias em ecoturismo, constata-se, que a psicologia do desenvolvimento vem estudando bastante o problema e conceitos antes considerados absolutos sofreram uma importante transformação. Dessa forma, não se deve a priori tecer qualquer afirmação categórica sobre o processo de desenvolvimento humano, assim como não se pode aplicar o mesmo modelo de desenvolvimento a qualquer pessoa, independentemente do momento histórico e da realidade sociocultural em que ela se insere.

Esses estudos demonstram que, por compartilhar um mesmo momento histórico da evolução, os seres humanos se assemelham, mas isso relativiza-se sob certos aspectos, uma vez que os grupos contemporâneos apresentam diferenças significativas quanto a modos de produção, utilização de instrumentos, uso da linguagem, relação com o mundo natural, produção cultural e desenvolvimento tecnológico. Cada um desses fatores equivalem-se 
no aparato orgânico do ser humano e constituem especificidades tanto nos processos perceptivos, como na construção de categorias mentais de apreensão, compreensão e transformação do real. Essa contribuição revela a complexidade e pluralidade do indivíduo.

$\mathrm{Na}$ formação de guias em ecoturismo, deve-se prepará-lo para contato futuro com pessoas de diversas etnias, culturas, profissões e vivências. Por isso, o profissional necessita, antes de tudo, tentar conhecê-las um pouco, antes de começar qualquer tipo de explanação ou conversa.

Também se deve levar em conta que o indivíduo pode se transformar na interação com o meio em que se insere e, ao aproveitar as situações de vivências nas trilhas o guia pode incentivar mudanças.

O paradigma experimental behaviorista trouxe a concepção $S-R$ (estímulo/resposta) na educação, privilegiando uma abordagem mecanicista do processo de ensino-aprendizagem e reduzindo, notoriamente, a ação do sujeito e sua automomia face a um ambiente controlador de sua ação. $O$ aparecimento e a evolução das teorias da área de cognição e das teorias interacionistas superam a ótica da aprendizagem com um processo linear e recolocam o sujeito como um elemento ativo de seu processo de construção de conhecimento.

O guia também deve se conscientizar de que não deve apenas reproduzir conhecimentos, assim como não cabe ao visitante simplesmente assimilá-los. Este aproveitará muito mais a sua visita se o reconhecerem como sujeito que questiona, propõe e constrói conhecimentos juntamente com o grupo, ressignificando o que já sabia e interagindo com o ambiente e a cultura de determinada localidade.

Desde Vygotsky até Valsiner, o desenvolvimento psicológico, visto sob ótica prospectiva, para além do momento atual, privilegia o que pode acontecer na trajetória do indivíduo. Em termos de atuação pedagógica, essa postulação engloba a idéia de que o guia deve provocar nos visitantes avanços que não ocorreriam espontaneamente.

Outra contribuição dessas perspectivas à formação do guia de ecoturismo, ressalta a importância da atuação dos outros membros do grupo 
social na mediação entre a cultura e o indivíduo e na promoção dos processos interpsicológicos que se internalizarão posteriormente.

Enfim, em todas essas teorias, nota-se a importância da interação no processo de desenvolvimento e de aquisição de conhecimentos, de maneira que se coloquem problemas reais para o visitante, visando que ele reflita sobre eles e construa propostas de intervenção sobre os mesmos. Isso pode ocorrer tanto a partir dos conhecimentos que já possuem, como também, daqueles a construírem-se no futuro, num processo interativo. De acordo com essas teorias, essa apropriação de novos conhecimentos revela-se de fundamental importância na constituição e ampliação dos mecanismos cognitivos do sujeito.

Pode-se deduzir, a partir das teorias vistas, que a melhoria da formação de guias ou educadores, não conta apenas com a psicologia do desenvolvimento ou de outras áreas isoladas, mas também exigem a interação de áreas do conhecimento tais como a filosofia, lingüística, biologia, sociologia e antropologia. Todo o trabalho desses estudiosos demonstra o fato de cada área de conhecimento possuir limites para a compreensão dos processos de crescimento e desenvolvimento, exigindo-se que se estabeleça um quadro teórico suficientemente amplo para abranger os aspectos biológicos, evolutivos e culturais do desenvolvimento humano, considerando-se naturalmente a ontogênese e a filogênese.

Apesar disso, a psicologia, ao apontar os processos pelos quais o ser humano se apropria do conhecimento formal e as categorias de pensamento a eles associados, contribui com a educação no sentido de elaborar a dinâmica guia-conhecimento-visitante no ambiente natural. Tais referenciais teóricos consideram os processos pedagógicos como intencionais, deliberados e dirigidos à construção de seres psicológicos, aos membros de uma cultura específica, cujo perfil, portanto, baliza-se por parâmetros culturalmente definidos. Os mecanismos de desenvolvimento atrelam-se aos processos de aprendizado, essenciais à emergência de características pedagógicas tipicamente humanas, que transcendem à programação biológica da espécie. 
Aos cursos de formação de guias e/ou condutores de visitantes, portanto, cabe a responsabilidade de fornecer instrumental para que os indivíduos possam interagir tanto com 0 conhecimento acumulado historicamente, como com a construção de conhecimento de forma sistêmica e intensa, potencializando os efeitos da outras conquistas culturais sobre os modos de pensamento.

As contribuições da psicologia aqui apresentadas fornecem apenas pressupostos teóricos colaborando com aqueles que buscam alternativas que auxiliem na construção de uma proposta de formação de guias de visitantes, em um estudo posterior pode-se partir da análise de propostas já existentes e destes subsídios teóricos para construção de linhas metodológicas que possam aprimorar o processo educativo em cursos de formação de guias de visitantes. 


\section{REFERÊNCIAS BIBLIOGRÁFICAS}

AZEVEDO, J. C. Novos paradigmas e a formação de professores. Em: Pátio. ano $\mathrm{V}$, n. 17,2000 , p. 51-53.

BALTES, P.B. Life-span developmental psychology: some converging observation on history and theory. Em: P.B. Baltes e O. G,Brin, Jr. (edf) Lifespan development and behavior. Vol. 2. New York: academic press.

BARROS, M.P. Modelo de planejamento para implantação e desenvolvimento do ecoturismo: diagnóstico ecoturístico - Estudo de caso. Dissertação de Mestrado. Programa de Pós-Graduação em Engenharia de Produção, Universidade Federal de Santa Catarina, 1999.

BRONFENBRENNER, U. A ecologia do desenvolvimento humano: experimentos naturais e planejados. Porto Alegre: Artes Médicas, 1996, p. 267.

DENKER, M. F. de Ada. Métodos e Técnicas de Pesquisa em Turismo. São Paulo: Futura, 2002, p. 286.

EMBRATUR- Diretrizes para Uma Política Nacional de Ecoturismo. Brasília, 1994, p.19.

GÖNCÜ, A. Children's and researchers' engagement in the world. Em: A Göncü Children's engagemente in the world: sociocultural perspectives. Cambridge: Cambridge University Press, 1999, p. 03-22.

HEDEGAARD, M; CHAIKLIN, S. \& Jensen, U.J. Activitu Theory and social pratice: an introduction. Em: Activity Theory and Social Pratice. Aarthus: DK Aarthus University Press,1999, p. 12-30. 
LIMA, E.C.A.S. O conhecimento psicológico e suas relações com a educação. Em: Em Aberto. ano 9, n. 48, 1990, p. 3-24

LOUREIRO, Carlos. LAYARGUES, Philippe. CASTRO, Ronaldo.(orgs). Sociedade e Meio Ambiente: a educação ambiental em debate. São Paulo: Cortez, 2000, p. 183.

MINISTÉRIO DO MEIO AMBIENTE. Ecoturismo: visitar para conservar e desenvolver a Amazônia / Manual de ecoturismo elaborado por : Luiz Fernando Ferreira; Maria do Carmo Barêa Coutinho. Brasília: MMA/SCA/Proecotur, 2002, p.27.

MINISTÉRIO DO MEIO AMBIENTE. Educação Ambiental: Curso básico a distância: educação e educação ambiental. Coordenação-Geral: Ana Lúcia Tostes de Aquino Leite e Naná Mininni- Medina. Brasíla: 2001.Volume I, p.5863.

REIGOTA, Marcos. Meio ambiente e representação social. 4 ed. São Paulo: Cortez, 2001, p.87.

RUSCHEL e ASSOCIADOS. $1^{\text {a }}$ Bienal de Ecoturismo de Canela. São Paulo/ Canela. Ruchel \& Associados. Marketing Ecológico / WWF/ SEBRAE - RS.

SALVATTI, S. S. Ecoturismo no pantanal Brasileiro e Boliviano: estudo de políticas e alternativas sustentáveis. São Paulo. Dissertação de mestrado. Programa de Pós -Graduação em Integração da América Latina, Universidade de São Paulo, 2002.

SALVATTI, S.S. Artigos: Interpretação da Natureza- Conceitos e Técnicas. Disponível em: <http://www.sites.uol.com.br/ecosfera/int/amb.html> .Acesso em: 20 de fevereiro de 2003.

TOLMAN, C.W. The Origins os Activity as a Category in the Philosophies of Kant, Fichte, Hegel and Marx. Em: Seth Chaiklin The theory and Practice of 
Cultural-historical Psychology. Aarthus: DK Aarthus University Press, 2001, p.84-92.

VALSINER, J. Constructing the Personal through the Cultural: redundant organization of psychological development. Em: Amsel, E e Renninger K.A. Change and Development: issues of theory, method and application. London: Lawrence Erlbaum Associates Publishers,1997, p. 27-42.

VYGOTSKY, L. S. Teoria e Método em Psicologia. São Paulo: Martins Fontes, 1999, p. 529.

WALLON, H. A evolução do pensamento da criança. SP: Martins Fontes, 1968, p. 226.

WEARING, $S$ e NEIL, J. Ecoturismo: impactos, potencialidades e possibilidades.1ª ed. São Paulo: Manole, 2001, p.256. 